\title{
Herbify: Aplikasi Perangkat Bergerak Berbasis Komputasi Awan Untuk Mengidentifikasi Tanaman Herbal Indonesia Menggunakan Cnn Model Xception
}

\author{
Arif Tirtana ${ }^{1}$, Maria Gita Teresa Febriani ${ }^{2}$, Dyas Irvan Masrui ${ }^{3}$, Amelia Arta Aisyah ${ }^{4}$ \\ ${ }^{1,3}$ Program Studi Teknik Informatika, STIKI Malang, Malang, Indonesia \\ ${ }^{2,4}$ Program Studi Sistem Informasi, STIKI Malang, Malang, Indonesia \\ email:1arif.tirtana@stiki.ac.id
}

\begin{abstract}
Abstrak
Jumlah tanaman herbal yang terdapat di Indonesia 30.000 jenis, namun hanya 1.200 jenis dari seluruh jenis tumbuhan obat yang sudah dimanfaatkan sebagai bahan baku obat herbal. Padahal tanaman herbal menyumbang pendapatan negara sebesar 150 miliar dollar pada tahuun 2020. Salah satu penyebabnya adalah kurangnya pengetahuan masyarakat Indonesia terhadap tanaman herbal Indonesia. Untuk meningkatkan wawasan tersebut dibutuhkan aplikasi yang dapat digunakan untuk mengidentifikasi tanaman herbal. Untuk itu dalam penelitian ini mengusulkan Herbify sebagai aplikasi perangkat bergerak berbasis komputasi awan dengan menggunakan metode CNN model Xception. Hasil dari penelitian ini menunjukkan bahwa Herbify mampu untuk mengidentifikasi tanaman herbal Indonesia dengan tingkat akurasi yang memuaskan yakni sebesar 96,3\%.
\end{abstract}

Kata Kunci: tanaman herbal, convolutional neural network, xception, komputasi awan.

\section{Abstract}

The number of herbal plants found in Indonesia is 30,000 species, but only 1,200 species of all types of medicinal plants have been used as raw materials for herbal medicines. Even though herbal plants contribute to state revenue of 150 billion dollars in 2020. One of the reasons is the lack of knowledge of Indonesian people about Indonesian herbal plants. To increase this insight, an application that can be used to identify herbal plants is needed. For this reason, this study proposes Herbify as a cloud computing-based mobile application using the CNN Xception model. The results of this study indicate that Herbify is able to identify Indonesian herbal plants with a satisfactory accuracy rate of $96.3 \%$.

Keywords: herbal plants, convolutional neural network, xception, cloud computing 


\section{PENDAHULUAN}

Di seluruh dunia total terdapat sekitar 40.000 jenis tumbuhan obat yang telah dikenal di dunia (WHO Report, 2019). Pada tahun 2020 ditaksir nilai perdagangan tanaman herbal di dunia mencapai 60 miliar dollar dan pada tahun 2050 nilai tanaman obat diprediksi mencapai 5 triliun dollar, hal tersebut dikarenakan permintaan akan tanaman obat meningkat sekitar 15-25\% per tahun (Express, 2004). Secara rinci pasar terbesar tanaman herbal berturut-turut adalah Asia sebesar 39\%, Eropa 34\%, Amerika Utara 22\%, dan sisanya tesebar diberbagai penjuru dunia sbesar 5\% (PT Industri Jamu Dan Farmasi Sido Muncul Tbk, 2020). Namun prediksi nilai tersebut kemungkinan besar akan semakin meningkat dikarenakan adanya pandemi yang meningkatkan kebutuhan akan tanaman obat diseluruh dunia sebagai bahan baku untuk obat herbal sebesar 4,7 kali lipat jika dibandingkan dengan kondisi normal. Hal tersebut menyebabkan tingkat pertumbuhan tahunan meningkat sebesar 10\% (Fact.MR, 2020).

Untuk wilayah Indonesia pada tahun 2020 nilai perdagangan produk herbal di Indonesia ditaksir mencapai 150 miliar dollar, namun total nilai penjualan produk Indonesia tersebut belum mencapai 1\% dari total nilai penjualan tanaman herbal dunia. Padahal di satu sisi kebutuhan akan tanaman herbal karena adanya pandemi di pasar Indonesia meningkat sebesar 20\%-30\% dari kondisi normal (Fact.MR, 2020). Secara total terdapat 30.000 jenis tumbuhan obat yang terdapat di Indonesia (WHO Report, 2019), namun dari jumlah tersebut hanya sekitar 1.200 jenis atau 5\% dari seluruh jenis tumbuhan obat yang sudah dimanfaatkan sebagai bahan baku obat herbal (PT Industri Jamu Dan Farmasi Sido Muncul Tbk, 2020). Hal tersebut dikarenakan kurang populernya tanaman obat di Indonesia jika dibadingkan dengan tanaman penghasil bahan makan seperti sayur-sayuran, umbi-umbian dan buah-buahan (Salim and Munadi, 2017). Kurang populernya tanaman obat tersebut disebabkan kurangnya pengetahuan serta wawasan masyarakat terkait dengan tanaman herbal dan manfaatnya (Salim and Munadi, 2017). Maka dari itu peningkatan pengetahuan masyarakat akan tanaman herbal Indonesia serta manfaatnya menjadi fokus utama dalam penelitian ini. Sehingga pada penelitian ini merancang sebuah sistem untuk mengenali obyek dalam gambar (image recognition).

Untuk mengidentifikasi obyek dalam gambar diperlukan adanya algoritma atau metode untuk mengenali obyek di dalam gambar (image recognition). Metode Convolutional Neural Network (CNN) terbukti memiliki tingkat akurasi yang paling baik (state-of-the-art) dibandingkan beberapa metode lain (Sandhopi, Lukman Zaman P.C.S.W and Yosi Kristian, 2020). Metode CNN merupakan pengembangan dari Artificial Neural Network (ANN) (Pangestu and Bunyamin, 2018) dan sampai saat ini masih menjadi metode yang banyak dibahas pada penelitian image recognition (Prasetyo et al., 2021). Dalam metode CNN terdapat beberapa model seperti Resnet, Inception, dan Xception (Sandhopi, Lukman Zaman P.C.S.W and Yosi Kristian, 2020). Pada penelitian (Sandhopi, Lukman Zaman P.C.S.W and Yosi Kristian, 2020) metode CNN dengan model Xception memiliki hasil pengujian paling baik untuk mengklasifikasikan objek ukiran dan motif batik. Sedangkan pada penelitian (Pangestu and Bunyamin, 2018) model Xception memiliki tingkat akurasi terbaik yakni $98,7 \%$ untuk mengenali anjing pada gambar. Sehingga dari kajian literatur yang telah dilakukan diharapkan metode CNN dengan model Xception mampu untuk mengidentifikasi tanaman herbal Indonesia.

Penerapan metode CNN dengan model Xception sebelumnya telah diimplementasikan pada beberapa jenis platform seperti website (Pangestu and Bunyamin, 2018) dan perangkat bergerak (Rangarajan and Ramachandran, 2021). Namun aplikasi perangkat bergerak (mobile application) memiliki kelebihan yaitu dapat mempermudah penggunaan dan dari sisi tampilan antarmuka pengguna lebih baik jika dibandingkan platform website yang harus diakses melalui browser (Gunawan and Saputro, 2018). Pada beberapa penelitian sebelumnya untuk menghemat waktu dalam proses pengembangan algoritma $\mathrm{CNN}$, terdapat beberapa model $\mathrm{CNN}$ yang sudah mengalami proses training yang telah disimpan dalam bentuk pre-trained model. Keras merupakan high level API yang seringkali digunakan dalam beberapa penelitian jaringan saraf tiruan yang menyediakan beberapa pre-trained model termasuk Xception. Metode CNN dengan model Xception merupakan state-of-the art dari model

20 | Herbify: Aplikasi Perangkat Bergerak Berbasis Komputasi Awan Untuk Mengidentifikasi Tanaman Herb... 
image recognition (Pangestu and Bunyamin, 2018). Terdapat dua kontribusi keilmuan pada penelitian ini, yang pertama adalah memperluas penerapan algoritma CNN dengan model Xception untuk mengidentifikasi gambar tanaman herbal Indonesi, dan yang kedua adalah merancang dan mengimplementasikan arsitektur aplikasi perangkat bergerak berbasis komputasi awan untuk mengidentifikasi tanaman herbal Indonesia menggunakan metode CNN model Xception.

\section{METODE PENELITIAN}

Metode penelitian yang digunakan pada penelitian ini secara garis besar dapat diilustrasikan pada Gambar 1.

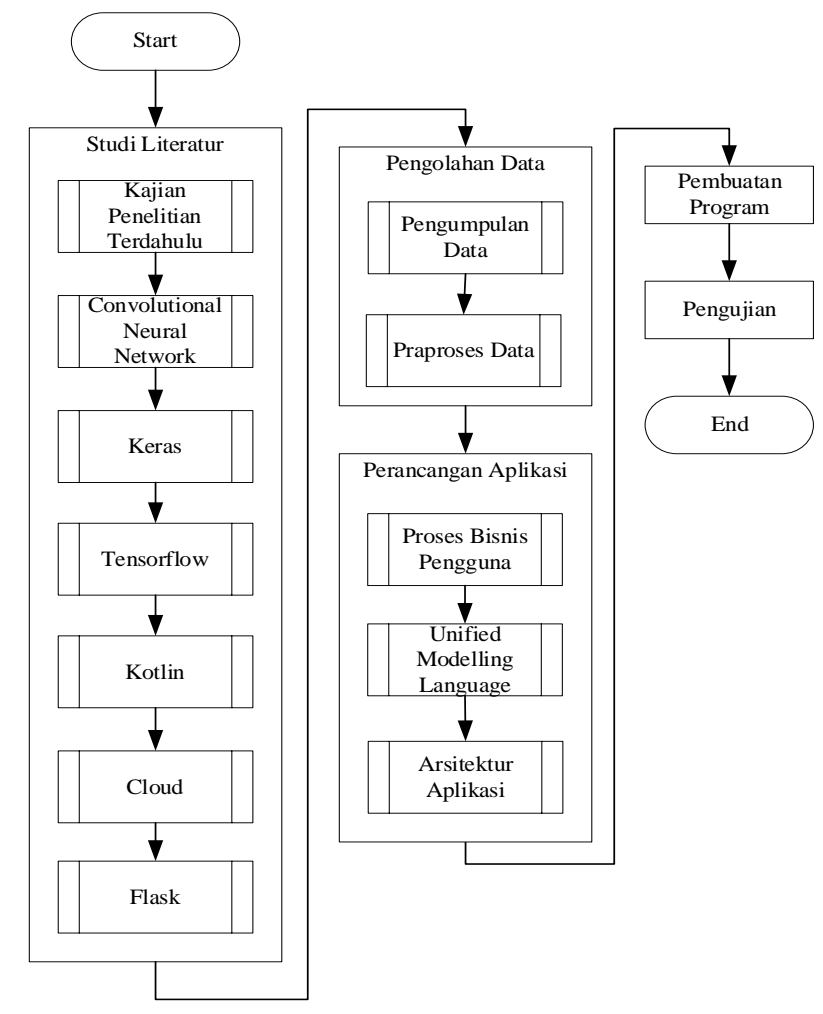

Gambar 1. Metode Penelitian Herbify

\section{Kajian Penelitian Terdahulu}

Penelitian pertama dilakukan oleh (Prasetyo et al., 2021) pada penelitian tersebut menggunakan CNN untuk mengklasifikan kesegaran ikan bandeng berdasarkan citra mata. Penelitian tersebut bertujuan untuk membandingkan beberapa model CNN seperti Xception, MobileNet V1, ResNet50, dan VGG16. Hasil dari penelitian tersebut menunjukkan bahwa model Xception memiliki tingkat akurasi sebesar 77\%. Penelitian kedua dilakukan oleh (Pangestu and Bunyamin, 2018) pada penelitian tersebut metode CNN digunakan untuk mendeteksi ras anjing pada gambar. Penelitian tersebut membandingkan tiga pre-trained model yaitu ResNet50, Xception, dan VGG16. Hasil dari penelitian tersebut menunjukkan bahwa Xception memiliki akurasi yang paling baik jika dibandingkan dengan model lain dengan tingkat akurasi sebesar $67,1 \%$. Penelitian ketiga dilakukan oleh (Sandhopi, Lukman Zaman P.C.S.W and Yosi Kristian, 2020) yang menggunakan metode CNN untuk mengidentifikasi motif Jepara pada ukiran. Pada penelitian tersebut membandingkan beberapa model CNN salah satunya adalah Xception. Hasil performa model Xception untuk mengenali motif Jepara mencapai 81\% pada gambar format RGB. Penelitian keempat ditulis oleh (Ihsan, 2021) yang menggunakan metode CNN untuk 
meneliti data radar. Hasil dari penelitian tersebut menunjukkan bahwa metode CNN berhasil untuk mengklasifikan data radar dengan tingkat akurasi sebesar 96,6\%.

Adapun perbedaan yang diusulkan dalam penelitian ini jika dibandingkan dengan penelitian yang telah dijelaskan diatas adalah penggunaan dataset yang digunakan sebagai data uji yakni tanaman herbal dalam gambar. Selain itu dalam penelitian ini menggunakan komputasi awan untuk melakukan pemrosesan data dan menerapkan metode CNN dengan model Xception sehingga dari penelitian ini dapat memperkaya implementasi metode CNN dengan model Xception serta arsitektur sistemnya.

\section{Convolutional Neural Network (CNN)}

Pada penelitian ini menggunakan metode Convolutional Neural Network (CNN) yang merupakan pengembangan dari Multilayer Perceptron (MLP) yang ditujukan untuk melengkapi kekurangan yang terdapat pada Articial Neural Network (ANN) dengan menggunakan single-layer perceptron dalam menghadapi operasi logika yang kompleks (Pangestu and Bunyamin, 2018).

Pada penelitian ini menggunakan jaringan konvolusi Xception atau Extream Inception merupakan pengembangan dari model Inception konvensional yang memiliki total 36 lapisan konvolusional yang membentuk basis jaringan ekstraksi fitur (Chollet, 2017). Pada masing-masing lapiran konvolusional dipisahkan oleh jaringan residual yang juga berfungsi untuk menghubungkan satu sama lain. Secara detail arsitektur Xception terdapat pada Gambar 2 di bawah ini.

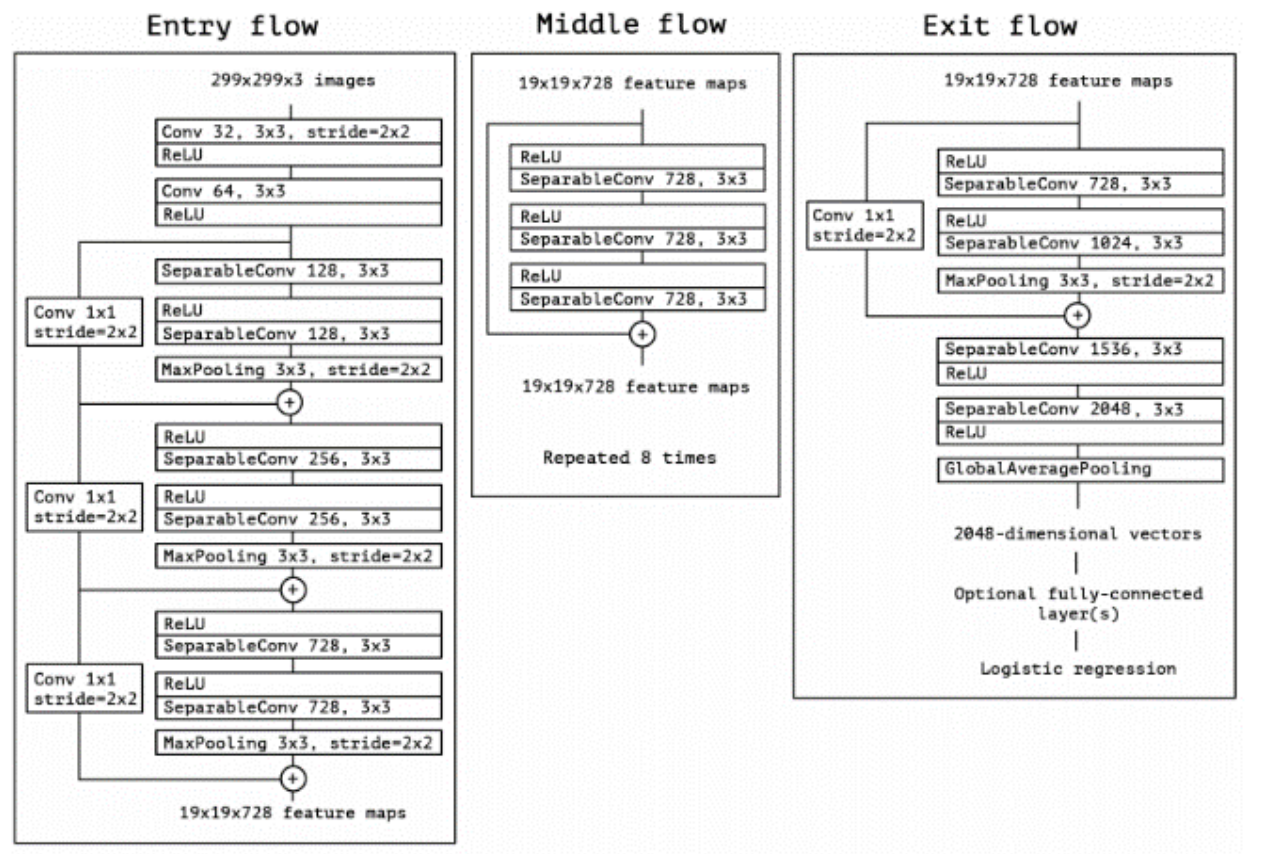

Gambar 2. Arsitektur Xception

\section{Keras}

Keras merupakan Application Programming Interface (API) yang ditulis dalam bahasa Python dan dapat dijalankan diatas framework machine learning seperti Tensorflow, CNTK, dan Theano. Keras dapat mendukung beberapa jaringan saraf tiruan seperti ANN dan CNN (Santoso and Ariyanto, 2018). Dalam Keras juga disediakan Keras Applications yang merupakan model deep learning yang digunakan bersama pre-training (Pangestu and Bunyamin, 2018). Model yang terdapat dalam Keras yaitu InceptionV3, VGG16, VGG19, dan Xception. Pada penelitian ini menggunakan pre-trained model Keras yaitu Xception.

\section{Tensorflow}

Tensorflow merupakan kerangka kerja (framework) pembelajaran mesin yang dirilis oleh Google untuk mendukung pengembangan penelitian berbasis komputer cerdas (Nurfita and Ariyanto, 2018). Tensorflow bekerja dalam skala yang besar dalam lingkungan (environment) yang heterogen

22 | Herbify: Aplikasi Perangkat Bergerak Berbasis Komputasi Awan Untuk Mengidentifikasi Tanaman Herb... 
(Pangestu and Bunyamin, 2018) dan menyediakan interface yang berfungsi untuk menerapkan metode machine learning secara fleksibel dan dapat diterapkan pada berbagai platform. Pada penelitian ini Tensorflow digunakan sebagai backend framework untuk Keras.

\section{Kotlin}

Kotlin merupakan bahasa pemrograman yang digunakan untuk mengembangkan aplikasi perangkat bergerak. Terdapat beberapa keunggulan bahasa pemrograman Kotlin yaitu merupakan bahasa pemrograman yang modern yang lebih mudah untuk dipelajari serta sederhana yang memungkinkan untuk meningkatkan efisiensi dalam jumlah kode (Fernanda et al., 2019). Kotlin memiliki kelebihan salah satunya adalah adanya null safety atau adanya penanganan terhadap kesalahan null pointer exception yang juga seringkali disebut "the billion dollar mistake" oleh banyak programmer. Dalam penelitian ini menggunakan bahasa Kotlin untuk mengembangkan aplikasi serta menggunakan IDE Android Studio.

\section{Komputasi Awan}

Komputasi awan (cloud computing) adalah sebuah mekanisme dimana sekumpulan sumber daya teknologi informasi saling terhubung dan tidak memiliki batasan fisik, mencakup infrastruktur maupun perangkat lunak yang secara keseluruhan dikelola oleh pihak ketiga yang memungkinkan pengguna untuk memaksimalkan penggunaan sumber daya secara on-demand melalui jaringan private maupun public (Rumetna, 2018).

\section{Flask}

Flask merupakan sebuah framework yang ditulis dengan bahasa Python dan merupakan jenis microframework. Flask merupakan microframework karena tidak memerlukan tools maupun libraries yang terdapat dalam sebuah basis data (Lee et al., 2018) (Lee et al., 2018). Dikarenakan fungsi dan komponen tersebut sudah tersedia dan dapat menggunakan ekstensi yang memungkinkan fitur dan komponen dapat diimplementasikan oleh Flask sendiri. Pada penelitian ini compute engine yang digunakan yakni N1, dengan type G1 Small dengan Virtual CPU 1 Shared Core dan memory 1.7 GB. yang cukup untuk menjalankan sebuah REST API. Menggunakan sistem operasi Debian serta penggunaan port TCP 8080. Pada penelitian ini Flask digunakan untuk mengimplementasikan aplikasi dan metode yang dibuat sebelumnya pada environment cloud untuk mempermudha fleksibilitas serta skalabilitas aplikasi. Kemudian hasil dari perhitungan disimpan pada Cloud Storage yang dilakukan pada proses REST API sebelumnya. Kemudian pada aplikasi Herbify menggunakan Cloud Firestore sebagai penyimpanan aset aplikasi yang digunakan, seperti data tumbuhan, data resep dan feedback hasil scan gambar. Secara detail proses komputasi awan pada aplikasi ini terdapat pada Gambar 3.

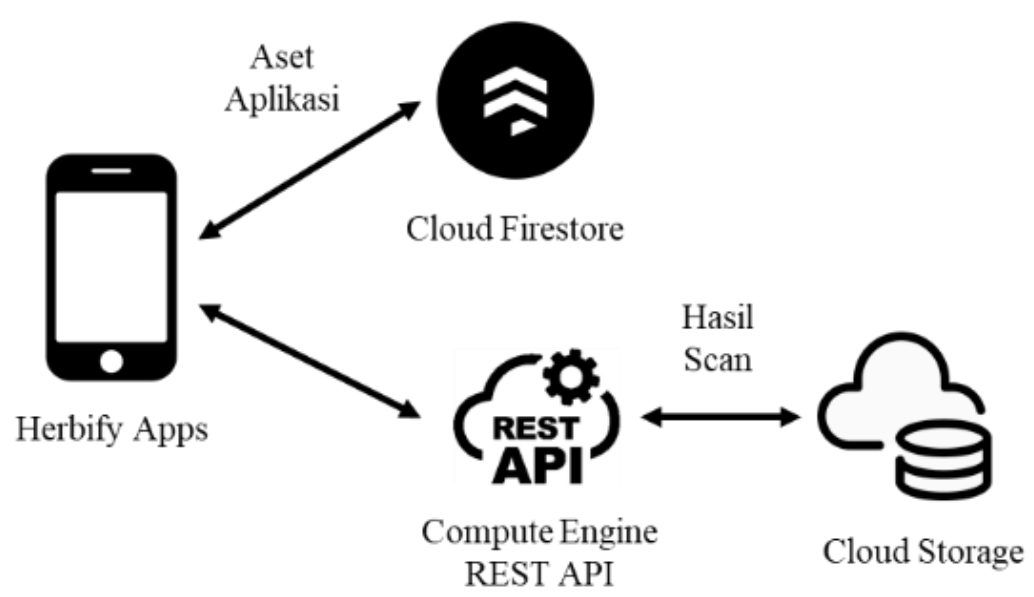

Gambar 3. Arsitektur Komputasi Awan Herbify 


\section{Pengolahan Data}

Dataset

Pada penelitian ini menggunakan dataset berupa gambar yang didalamnya terdapat obyek tanaman herbal yang didapat dari mesin pencari Bing. Adapun proses pengumpulan data foto dilakukan menggunakan bing dataset generator (github.com/italojs/bing-dataset-generator) yang merupakan application programming interface (API) yang telah disediakan oleh microsoft. Dalam penelitian ini menggunakan 20 jenis dataset tanaman herbal yaitu adas, akar alang-alang, bawang putih, daun katuk, daun salam, jahe, kapulaga, kumis kucing, kunyit, lidah buaya, mengkudu, meniran, miana, pare, pegagan, rosela, seledri, serai, temu kunci, dan valerian. Dalam proses pengumpulan data menggunakan label pencarian data sebagai berikut ["Adas", "Akar Alang Alang", "Bawang Putih", "Daun Katuk", "Daun Salam", "Jahe", "Kapulaga", "Kumis Kucing", "Kunyit", "Lidah Buaya", "Mengkudu", "Meniran", "Miana", "Pare", "Pegagan", "Rosela", "Seledri", "Serai", "Temu Kunci", "Valerian"]. Total dataset yang digunakan dalam penelitian ini sebanyak 1.000 dataset dengan jumlah pada masing-masing gambar tanaman herbal sebanyak 50 gambar. Adapun contoh dataset tanaman herbal yang digunakan dalam penelitian ini terdapat pada Gambar 4 di bawah ini.

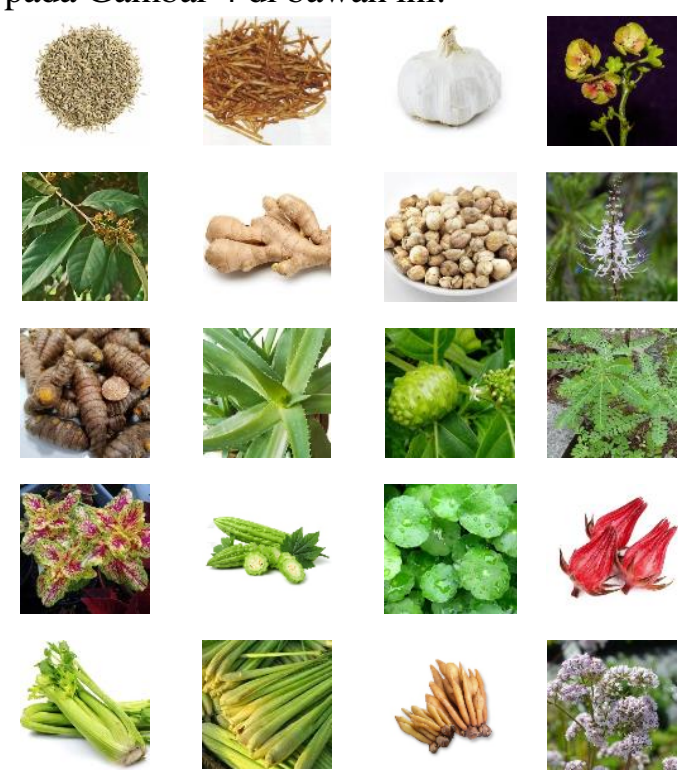

Gambar 4. Gambar Tanaman Herbal

Dataset dalam penelitian ini tergolong kecil sehingga perlu menggunakan transfer learning agar mencapai kinerja yang optimal. Salah satu teknik dalam transfer learning adalah fine tuning yang berfungsi menerapkan pelatihan ulang pada akhir tahap konvolusi dan tidak melatih ulang layer konvolusi lainnya. Proses ini berfungsi untuk memberikan generalisasi pada CNN yang berlaku untuk dataset lain dengan tetap mempertahankan generalisasi yang terdapat pada dataset original (Prasetyo et al., 2021).

\section{Praproses Data}

Setelah data terkumpul yang telah dijelaskan pada proses sebelumnya maka data gambar tersebut harus diolah melalui tahap praproses data sebelum data diproses kedalam metode CNN model Xception, adapun tahapannya yaitu pertama adalah Image Data Generator untuk pipelining data gambar untuk mengaktifkan fungsi deep learning. Tahap kedua adalah proses data validation, selanjutnya adalah data test, dan terakhir adalah pemberian label kelas pada gambar.

\section{Proses Bisnis Herbify}

Pada tahap awal akan dijelaskan proses bisnis penggunaan aplikasi yang dibagi menjadi dua yaitu proses front-end dan back-end. Pada proses bisnis front-end pengembangan Herbify menggunakan bahasa 24 | Herbify: Aplikasi Perangkat Bergerak Berbasis Komputasi Awan Untuk Mengidentifikasi Tanaman Herb... 
pemrograman Kotlin menggunakan IDE Android Studio. Sedangkan pada proses back-end menggunakan framework Tensorflow dan Keras untuk menjalankan algoritma CNN model Xception serta dijalankan pada environment Flask agar lebih mudah dan fleksibel apabila ada perubahan. Pada tahap pertama sistem yang telah dirancang mengirimkan gambar yang sebelumnya sudah dilakukan praproses ke API Keras untuk kemudian diidentifikasi apakah gambar yang diunggah oleh pengguna memiliki objek tanaman herbal didalamnya atau tidak. Secara detail proses front end dan back end dari aplikasi Herbify terdapat pada Gambar 5 di bawah ini.
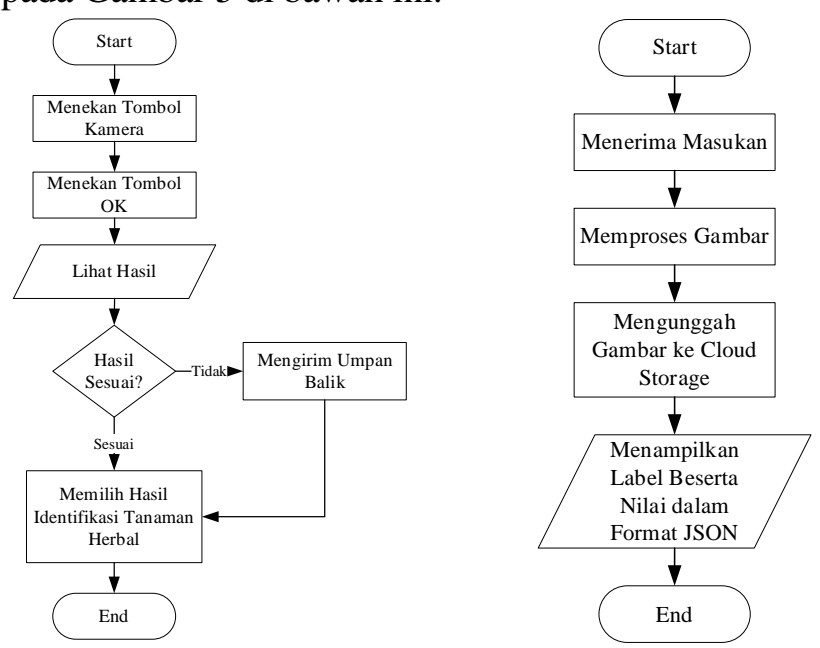

Gambar 5. Flowchart Proses Front-End \& Back-End

\section{Unified Modelling Language (UML)}

Untuk menyelaraskan antara kebutuhan pengguna terhadap sistem, maka dalam penelitian ini menggunakan UML (Tirtana et al., 2020). Adapun diagram use case dan activity ditunjukkan pada Gambar 6.

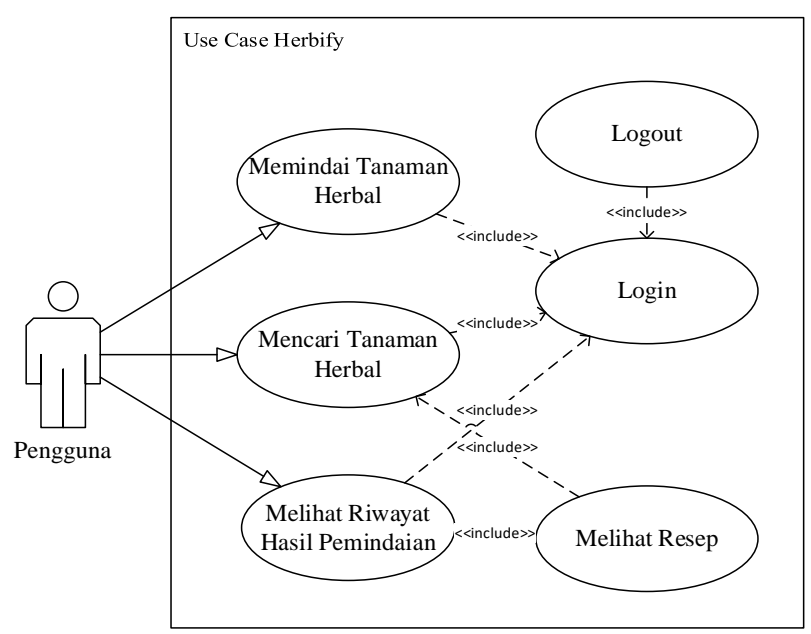

Gambar 6. Use Case Herbify

\section{Arsitektur Aplikasi}

Dari sisi architectural pattern, aplikasi ini mengadopsi MVVM (Model-View-ViewModel). Pada penelitian ini menggunakan dua layer architectural, yaitu UI layer dan Data Layer. UI layer berisi tampilan antarmuka. Sedangkan data layer bertugas untuk mengelola data baik dari web services maupun local data. Sebagaimana tugas ViewModel class yaitu berinteraksi dengan model yang berada di data layer dan juga menyiapkan observables yang akan diobservasi oleh Activity/Fragment class dari UI layer. Architectural pattern secara lebih jelas terdapat pada Gambar 7 di bawah ini. 


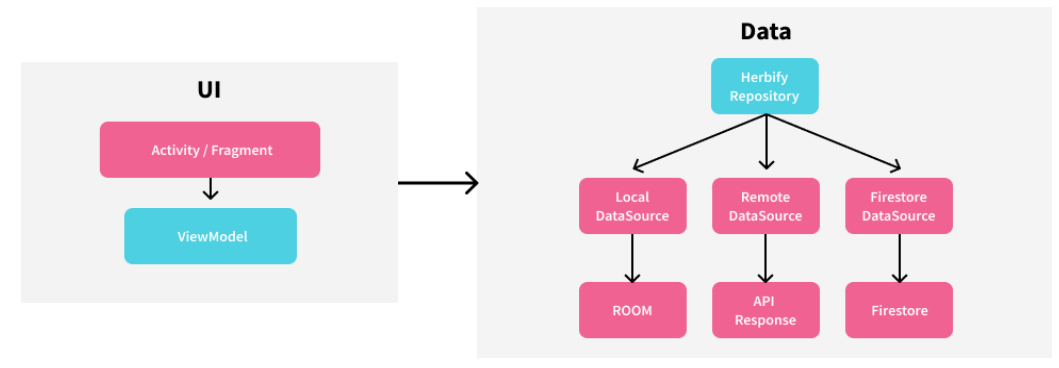

Gambar 7. Architectural Pattern Herbify

\section{HASIL DAN PEMBAHASAN}

Sesuai dengan tahap perancangan aplikasi diatas, maka tahap selanjutnya adalah tahap pembuatan program. Penerapan rancangan sistem ini menggunakan bahasa Kotlin dan Python, serta menggunakan database Cloud Firestore. Aplikasi ini berbasis android. Secara berturut-turut hasil aplikasi Herbify terdapat pada gambar di bawah ini.

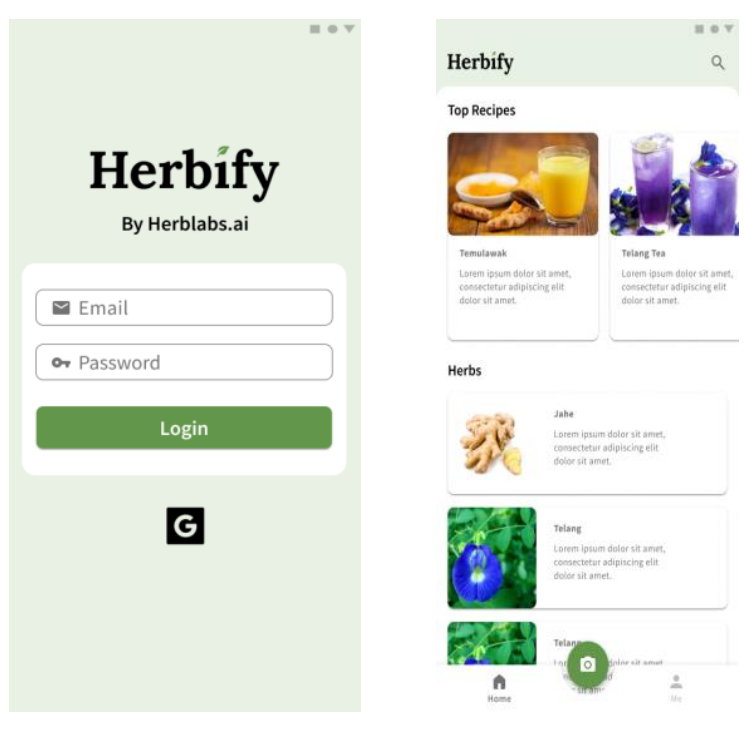

Gambar 8. Halaman Login \& Beranda
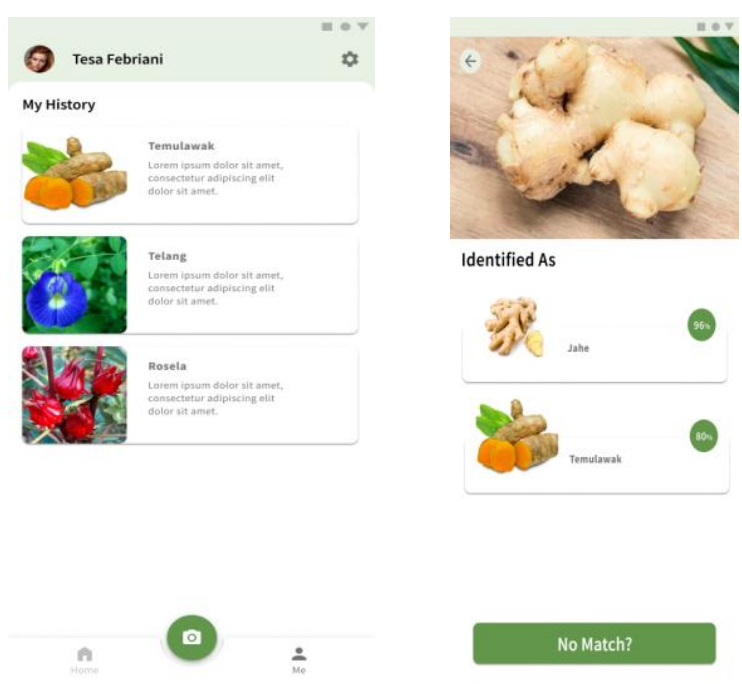

Gambar 9. Halaman Profil \& Pencarian Tanaman

26 | Herbify: Aplikasi Perangkat Bergerak Berbasis Komputasi Awan Untuk Mengidentifikasi Tanaman Herb... 


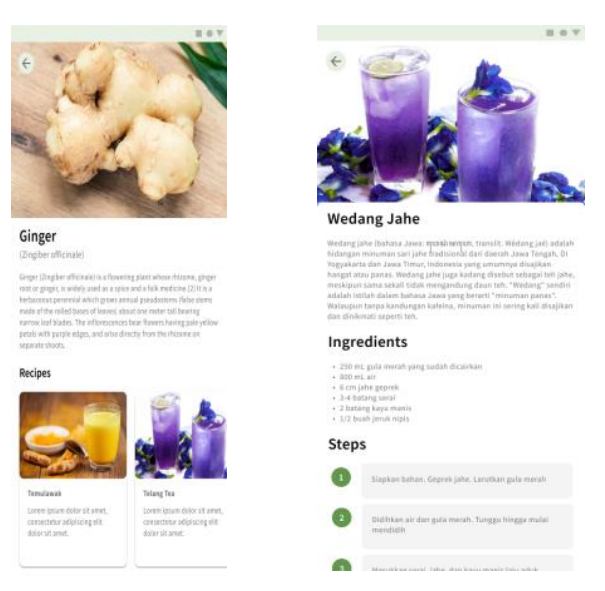

Gambar 10. Halaman Hasil Pemindaian \& Melihat Resep

\section{Pengujian}

Setelah aplikasi telah selesai dibuat, maka tahap selanjutnya adalah menguji tingkat akurasi pada metode CNN model Xception yang telah dibuat. Model yang telah dibuat akan diuji coba pada masing-masing jenis tanaman herbal yakni sejumlah 20 jenis dengan uji coba masing-masing satu gambar pada masing-masing jenis. Gambar yang diuji cobakan dipilih secara acak dari data latih yang telah dikumpulkan sebelumnya. Hasil akurasi prediksi disajikan dalam bentuk persentase kemudian diambil rata-rata persentase untuk mengetahui kinerja dari model yang telah dibangun. Adapun rangkuman hasil uji terdapat pada tabel di bawah ini. Untuk detail gambar yang diujikan terdapat pada lampiran.

Tabel 1. Hasil Pengujian Akurasi Herbify

\begin{tabular}{|c|c|}
\hline Nama Tumbuhan & Persentase Akurasi Gambar (\%) \\
\hline Adas & 100 \\
\hline Akar alang-alang & 100 \\
\hline Bawang Putih & 100 \\
\hline Daun Katuk & 73.66 \\
\hline Daun Salam & 94.31 \\
\hline Jahe & 99.98 \\
\hline Kapulaga & 100 \\
\hline Kumis Kucing & 100 \\
\hline Kunyit & 99.97 \\
\hline Lidah Buaya & 100 \\
\hline Mengkudu & 100 \\
\hline Meniran & 100 \\
\hline Miana & 99.98 \\
\hline Pare & 99.96 \\
\hline Pegagan & 100 \\
\hline Rosela & 100 \\
\hline Seledri & 58.1 \\
\hline Serai & 99.95 \\
\hline Temu Kunci & 100 \\
\hline Valerian & 100 \\
\hline $\bar{x}$ akurasi & 96.30 \\
\hline
\end{tabular}

\section{KESIMPULAN}

Hasil dari penelitian ini menunjukkan bahwa aplikasi Herbify mampu untuk mengidentifikasi tanaman herbal Indonesia yang ada pada gambar dengan menggunakan metode CNN model Xception. Hasil tersebut diharapkan mampu meningkatkan pengetahuan serta wawasan masyarakat Indonesia 
khususnya generasi Z yang kurang familiar terhadap jenis-jenis tanaman herbal dan manfaatnya. Dengan meningkatnya wawasan masyarakat Indonesia diharapkan dapat senantiasa meningkatkan tingkat kesehatan masyarakat, serta dapat meningkatkan perekonomian mikro pada level terkecil yaitu keluarga, dan tingkat ekonomi makro yaitu pendapatan negara dari sisi ekspor tanaman herbal.

Tingkat akurasi model yang dikembangkan sangat baik dengan tingkat akurasi sebesar 96,3\% . Hal ini dikarenakan penggunaan model Xception telah terbukti memiliki tingkat akurasi yang baik pada penelitian sebelumnya khususnya untuk proses pengenalan obyek dalam gambar (image recognition). Selain itu hasil dari penelitian ini membuktikan bahwa model Xception mampu untuk mengidentifikasi obyek tanaman herbal dengan baik.

Saran untuk penelitian selanjutnya, dapat menggunakan jumlah dataset yang lebih besar dengan harapan mampu meningkatkan hasil akurasi, serta menambahkan beberapa metode praproses khususnya untuk mengatasi gambar yang memiliki pencahayaan rendah. Serta membandingkan beberapa model lain seperti ResNet, MobileNet, dan VGG16 yang terbukti juga memiliki hasil yang baik dalam mengenali obyek dalam gambar (Rahimzadeh and Attar, 2020)

\section{UCAPAN TERIMA KASIH}

Ucapan terima kasih disampaikan kepada Kelompok Bidang Minat Program Studi Sistem Informasi Sekolah Tinggi Informatika dan Komputer Indonesia (STIKI) Malang yang memberikan wawasan serta fasilitas dalam mengembangkan artikel ilmiah ini

\section{DAFTAR PUSTAKA}

Chollet, F. (2017) 'Xception: Deep Learning with Depthwise Separable Convolutions', in 2017 IEEE Conference on Computer Vision and Pattern Recognition (CVPR). IEEE, pp. 1800-1807. doi: 10.1109/CVPR.2017.195.

Fact.MR (2020) Medicinal Herbs Market Size, Forecast \& Trend Analysis 2030, April 2020. Available at: https://www.factmr.com/report/4070/medicinal-herbs-market (Accessed: 27 July 2021).

Fernanda, F. et al. (2019) 'Pengembangan Aplikasi Mobile Pemesanan Jasa Laundry Berbasis Android', 3(7), pp. 6949-6955.

Gunawan, H. and Saputro, A. K. H. (2018) 'Pemanfataan Aplikasi Mobile Untuk Mempercepat Pencarian Tempat Indekos Berbasis Android', Jurnal Muara Sains, Teknologi, Kedokteran dan Ilmu Kesehatan, 1(2), pp. 85-96. doi: 10.24912/jmstkik.v1i2.1454.

Ihsan, C. N. (2021) 'Klasifikasi Data Radar Menggunakan Algoritma Convolutional Neural Network (CNN)', DoubleClick: Journal of Computer and Information Technology, 4(2), pp. 115-121.

Lee, S. et al. (2018) 'Learning Management Systems Use in Science Education', Procedia - Social and Behavioral Sciences. Elsevier B.V., 64(1), pp. 681-690. doi: 10.1016/j.sbspro.2014.07.429.

Nurfita, R. D. and Ariyanto, G. (2018) 'Implementasi Deep Learning Berbasis Tensorflow Untuk Pengenalan Sidik Jari', Emitor: Jurnal Teknik Elektro, 18(01), pp. 22-27. doi: 10.23917/emitor.v18i01.6236.

Pangestu, M. A. and Bunyamin, H. (2018) 'Analisis Performa dan Pengembangan Sistem Deteksi Ras Anjing pada Gambar dengan Menggunakan Pre-Trained CNN Model', Jurnal Teknik Informatika dan Sistem Informasi, 4, pp. 337-344.

Prasetyo, E. et al. (2021) 'Perbandingan Convolution Neural Network Untuk Klasifikasi a Comparison of Convolution Neural Network for Classifying Milkfish 'S Freshness on Eye Images', 8(3), pp. 601-608. doi: 10.25126/jtiik.202184369.

28 | Herbify: Aplikasi Perangkat Bergerak Berbasis Komputasi Awan Untuk Mengidentifikasi Tanaman Herb... 
PT Industri Jamu Dan Farmasi Sido Muncul Tbk (2020) Laporan Tahunan 2020.

Rahimzadeh, M. and Attar, A. (2020) 'A modified deep convolutional neural network for detecting COVID-19 and pneumonia from chest X-ray images based on the concatenation of Xception and ResNet50V2', Informatics in Medicine Unlocked. Elsevier Ltd, 19, p. 100360. doi: 10.1016/j.imu.2020.100360.

Rangarajan, A. K. and Ramachandran, H. K. (2021) 'A preliminary analysis of AI based smartphone application for diagnosis of COVID-19 using chest X-ray images', Expert Systems with Applications. Elsevier Ltd, 183(June), p. 115401. doi: 10.1016/j.eswa.2021.115401.

Rumetna, M. S. (2018) 'PEMANFAATAN CLOUD COMPUTING PADA DUNIA BISNIS: STUDI LITERATUR', Jurnal Teknologi Informasi dan Ilmu Komputer, 5(3), p. 305. doi: 10.25126/jtiik.201853595.

Salim, Z. and Munadi, E. (2017) Info Komoditi Tanaman Obat, Badan Pengkajian dan Pengembangan Perdagangan Republik Indonesia.

Sandhopi, Lukman Zaman P.C.S.W and Yosi Kristian (2020) 'Identifikasi Motif Jepara pada Ukiran dengan Memanfaatkan Convolutional Neural Network', Jurnal Nasional Teknik Elektro dan Teknologi Informasi, 9(4), pp. 403-413. doi: 10.22146/jnteti.v9i4.541.

Santoso, A. and Ariyanto, G. (2018) 'Implementasi Deep Learning Berbasis Keras Untuk Pengenalan Wajah', Emitor: Jurnal Teknik Elektro, 18(01), pp. 15-21. doi: 10.23917/emitor.v18i01.6235.

Tirtana, A. et al. (2020) 'Rancang Bangun Aplikasi E-Commerce Untuk Meningkatkan Pendapatan UMKM', Jurnal Ilmiah Teknologi Informasi Asia, 14(2), p. 101. doi: 10.32815/jitika.v14i2.473.

WHO Report (2019) WHO Global report on traditional and complementary medicine 2019, World Health Organization. Available at: https://apps.who.int/iris/bitstream/handle/10665/312342/9789241515436-eng.pdf?ua=1. 
